\title{
Készletek szerepe az ellátási láncban
}

\section{The Role of Stocks in the Supply Chain}

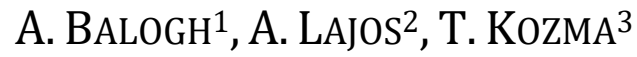 \\ ${ }^{1}$ Szent István University, Faculty of Economics and Social Sciences, antal.balogh73@gmail.com \\ 2Szent István University, Faculty of Economics and Social Sciences, lajos.attila@gtk.szie.hu \\ ${ }^{3}$ Szent István University, Faculty of Economics and Social Sciences, kozma.timea@gtk.szie.hu
}

Absztrakt. Az ellátási lánc teljesítményét nagymértékben befolyásolja a szereplók készleteinek összetétele, nagysága, rendelkezésre állása. A végső fogyasztókért vívott versenyben kiemelt szerepe van a kiszolgálási színvonalnak, hiszen az ellátási láncok ugyanazokért a fogyasztókért vívnak versenyt, és a fogyasztók döntése leginkább e két tényezô, mint a készlet nagyága és a kiszolgálás minőségétôl függ. A tanulmány a kkv-k logisztikai problémáit feltáró kutatás része, melynek célja rávilágítani a jellemző nehézségekre, és azokra a kihívásokra, amelyek legtöbbször elkerülik a logisztikai- vagy ellátási lánc vezető́k figyelmét. A fejlődố kkv méretü vállalkozások versenyképessége - ami magába foglalja a költségek nagyságát is, kapcsolódva a K+F tevékenységhez vagy vállalat növekedéshez - a lekötött tôke mértékével arányosan változhat, melynek jelentös részét képezik a készletek. A kutatásban résztvevő vállalat, a Diego Kereskedelmi Kft. készletezési politikáján keresztül kerül elemzésre a készletek összetétele, illetve a velük kapcsolatos kockázatok, illetve félreértések. A tanulmány célja továbbá a helyes megoldások elősegitése, melyhez szorosan kapcsolódik (az itt tárgyalásra nem kerülő) Lean megoldások támogató szerepe.

Kulcsszavak: kkv, ellátási lánc, információ megosztás, készletek

JEL besorolás: M11

\section{Bevezetés}

Bár az autóipar megtorpanása jelzés értékű, a magyar gazdaság továbbra is kedvező a gazdasági társaságok számra. A helyzetet kihasználva erősödni tudnak, újabb és újabb lehetőségek kerülnek a vállaltok elé, melyek nem csak pénzügyi helyzetüket befolyásolják, hanem létjogosultságukat erősíti, amit kihasználni megfelelő felkészültség mellett lehet.

A logisztika területe kiemelten fontos mind a napi müködés során, mind pedig a jövőre vonatkozó tervek megvalósításában. Szinte nincs olyan iparág - egy-két kivétellel - ahol a megfelelő logisztikai folyamatok és döntések ne befolyásolnák a vállalatok eredményességét, profit termelő képességét és nagymértékben a költségek alakulását. A kis- és középvállalkozások esetében is, mint a vállalatok egyik legnagyobb költsége, a 
logisztikai költségek a sikeres működést befolyásolják, ezért komoly szerepük van a logisztikai folyamatoknak és az ellátási láncnak, melyben a vállalatok részt vesznek.

A téma kiválasztásában fő motiváló szerepet jelentett kis- és középvállalkozások logisztikai rendszerének ismerete, ezen belül azok a megoldások, amelyek nem járulnak hatékonyan hozzá a sikeres működéshez. A kutatás célja feltárni azokat a lehetőségeket, amelyek útmutatást biztosíthatnak nehézségekkel küzdő vállalkozásoknak, segíteni tudják a hatékony működést.

A téma feldolgozása Magyarországi vállalkozások működése alapján történt, azonban következtetései és eredményei nemzetközi jelentőségűek. Mivel a példaként bemutatott vállalat is nemzetközi piacon tevékenykedik és ellátási lánca Európa határain túl mutat, a készletezési megoldások alkalmazása ellátási láncára építve, a nemzetközi piac anyagáramlásának bemutatása, és beszállítói- és vevői köre által kialakult megítélése is jól prezentálható. A kkv-k nem csak pénzügyi mutatók és azok adatai alapján alakítanak ki képet a globális piacon, hírnevüket befolyásolják az érintettek személyes tapasztalatai is.

A téma középpontjában tehát a kkv-k logisztikai problémái állnak, kiemelt figyelmet fordítva a raktározási tevékenységre, ami a vállalat átfogó logisztikai rendszerének egyik legfontosabb része. A magyar gazdaság erőteljes fejlődése szükségessé teszi fejlett és tudatos logisztikai rendszerek alkalmazását, amelyek a makro környezetben vállalati célok megvalósítását támogatják, és hozzájárulnak a gazdaság további növekedéséhez. A jól működő vállalatok logisztikai stratégiát alkalmazva, előremutató gondolkodással, a vállalati stratégiát valósítják meg, ami a hosszú távú siker alapja.

Az ellátási lánc, mint a gazdaság fizikai mozgató eszköze kiemelt szerepet kap a versenyképesség, hatékonyság és hosszú távon gazdaságosan működő üzleti vállalkozások életében. A kkv-k logisztikai problémái, illetve azok hatékony megoldásai a szakirodalom által rendszeresen érintett témakör. A vállalatok szempontjából egyik meghatározó pontja a kiszolgálási színvonal minősége, ami a kutatás egyik vezérfonala egyben. „A logisztikai kiszolgálási színvonal nem más, mint az értékesített termékekhez szorosan kapcsolódó szolgáltatások egy része, amelyet a logisztika „állít elő”. A vevő az eladó logisztikai teljesítményét közvetlenül a logisztikai kiszolgálási színvonalon keresztül ismerheti meg, illetve értékelheti." (Némon et al., 2005. 83. o.) Azonban ahhoz, hogy ez megvalósulhasson, a megelőző folyamatok minőségét is maximalizálni kell, ami az Ellátási Lánc Menedzsment (SCM) alapvető feladata.

A közhely, miszerint a legrosszabb rendszer is jobb, mintha nincs rendszer, a logisztika és ellátási lánc szemlélet szempontjából nem értelmezhető! Rendszer nélkül nincs ellátási lánc, ezért a kutatás is rendszerszemléletű megközelítésben, komplex vizsgálatként, a logisztikai terület legfontosabb részterületeire fókuszál. 
Az Ellátási Lánc Menedzsment „terméke” a kiszolgálási színvonal. A vállalatok arra törekednek, hogy ez a „termék” minél inkább a vásárlói igényeknek megfelelő, minőségét tekintve maximális, vagy ahhoz közeli értékű, a vállalatot jellemző megbízhatóságot tükrözze.

Üzletemberek emlékezet óta kitűzött célja, hogy a vállalatok hatékony üzleti modelleket dolgozzanak ki, melynek célja, hogy a vásárlói igényeket jobban elégítsék ki, mint versenytársaik. A siker tehát a vásárlók igényeinek kielégítésén múlik. Ahhoz, hogy erre a vállalatok képesek legyenek, megfelelő erőforrásokra és képességre van szükségük. A kérdés, hogyan tudnak értéket teremteni a beszállítók bevonásával? Az erőforrások megfelelő elosztása és a vállalati határokon túl nyúló együttműködés adja lényegét a sikeres Ellátási Lánc Menedzsmentnek. (Fawcett at al., 2014)

A kutatás központi témája, a kiszolgálási színvonal egyik meghatározó tényezője, a készletgazdálkodás. Az 1. ábra a kutatásban résztvevő vállalat (Diego) értékláncát mutatja be, kiemelve az egyes területek vevői elégedettséghez való hozzájárulását.

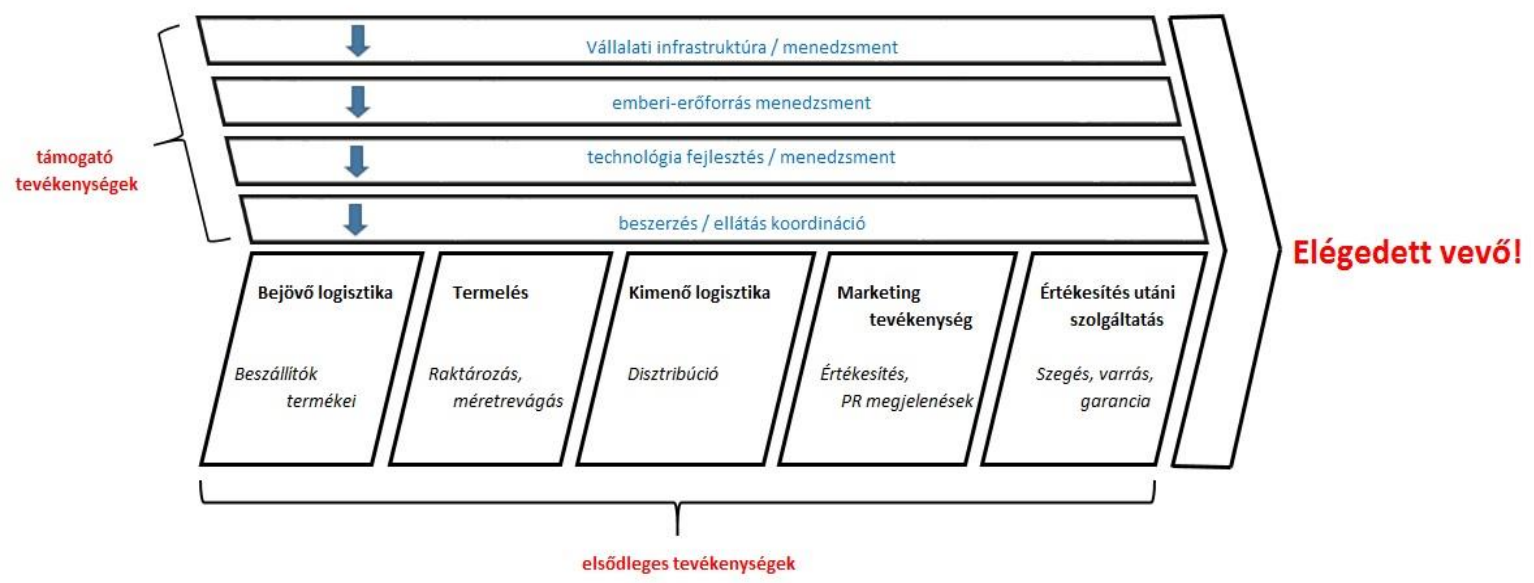

1. ábra. A Diego értéklánca

Forrás: Porter, 1985, 37. o. alapján, saját szerkesztés

Anyag és módszer

A kutatás módszertana a szakirodalom feldolgozásán, illetve a gyakorlatba átültetett megoldásokon alapszik, kiemelve a Diego $\mathrm{Kft}$. konkrét esetét, alapul véve a stratégia fontosságát és egyéb vállalatvezetési eszközöket. A szakirodalom párhuzamba vonása a gyakorlati alkalmazással, illetve a kkv-k által sok esetben kevésbé részletes és körültekintő elemzési módszerek feltárása, figyelmükre koncentrálása által kialakult gyakorlati példák helyes irányát mutatva, esetelemzés módszerével. A téma levezetése a nemzetközi ellátási láncokban múködő vállalatok részére iránymutató, a hasonló kihívásokkal küzdő termelő vagy szolgáltató vállalatok szükségszerű lépéseinek javaslataival. 
Az ellátási lánc

Az ellátási lánc nem más, mint „Értékteremtő - termelési és logisztikai - folyamatok együttműködő szervezeteken átívelő sorozata, mely fogyasztói igények kielégítésére alkalmas terméket, illetve szolgáltatást hoz létre" (Chikán, 2008).

A vállalati logisztikai rendszer tudatos, a vállalat versenyképességének javítását célzó kezelése, míg az ellátási lánc tudatos, a résztvevő vállalatok versenyképességének javítását célzó kezelése (Gelei, 2013). Egy olyan vállalat esetén, mint a Diego, kiemelt jelentőségű az üzlethálózatának versenyképessége, hiszen arányos a rentabilitással, a vállalati image-el, és a hálózat növekedés lehetőségeivel. Az ellátási lánc azon szervezetek, vállalatok összessége, amelyek közvetlenül részt vesznek a termékek és/vagy szolgáltatások ellátási és elosztási, illetve kapcsolódó információs és pénzügyi folyamataiban a forrástól a végső fogyasztóig (Oláh, et al, 2017). Továbbá, az ellátási lánc, mint szemléletmód nem csak együttműködő vállalatok láncát, hanem azok hálózatba szerveződését eredményezi, ami a piaci verseny jelenleg leghatékonyabb fogyasztóelérését valósítja meg.

Mindezek mellett fogyasztói igények kielégítéséről, a fogyasztókért vívott versenyről beszélünk. A fogyasztói igény „olyan igény, amelyet a gazdaság szereplői nem saját szervezetükön belül végzett munkával és nem is közösségi intézmények útján kívánnak kielégíteni" (Chikán, 2008.). Tehát a stratégia kialakítása meghatározza azokat a célokat, amelyek a fogyasztói igények kielégítése mellett, értékteremtő folyamatokon keresztül valósulnak meg.

A Diego egyszerűsített ellátási láncát a 2. ábra mutatja. A nagykereskedő szerepét betöltő Diego központ önálló szereplő, míg beszállító- és vevő partnerei többszörösek, így például a beszállítók alapanyagainak beszállítói köre hatványozódva értendő. Vevői (azaz bolthálózata) Magyarországon, Romániában és Szlovákiában több mint 150 áruházban fogadják a végső fogyasztókat.

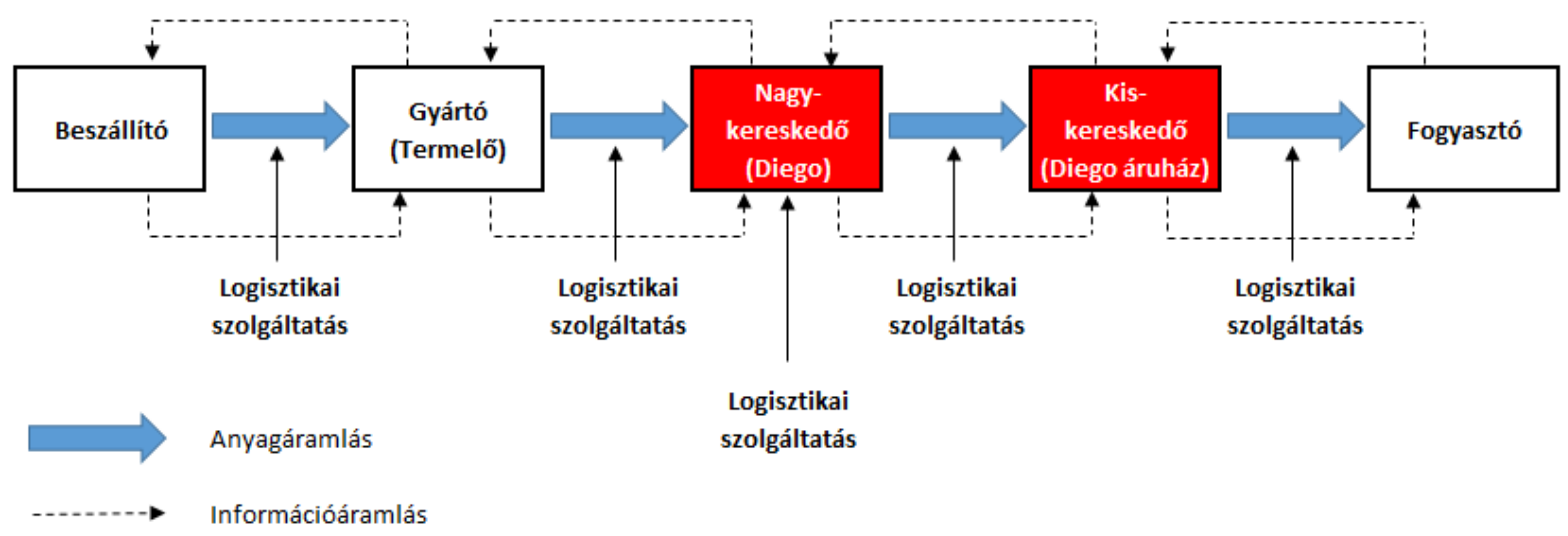

2. ábra: A Diego egyszerüsített ellátási lánc modellje

Forrás: Saját szerkesztés 
Minden vállalat ellátási lánchoz, sok esetben ellátási hálózathoz tartozik, több különböző szállítóval és partnerrel. A partnerkapcsolatok folyamatos növekedésben vannak, ami azt jelenti, hogy a vállalatok gyakran válnak más szervezetek ellátási lánc tagjává. (Morley, 2017) Bár hazánkban a kapcsolatok kiépítése sokkal nehezebben jön létre, mint más, főként nyugati országok esetén - aminek oka leginkább a bizalmatlanság - (Szegedi, 2017) az ellátási lánchoz vagy hálózathoz tartozás elkerülhetetlen, viszont sok előnyt jelentő lehetőség. Fontos szem előtt tartanunk, hogy az erőforrások megfelelő elosztása és a vállalati határokon túl nyúló együttműködés biztosítja az Ellátási Lánc Menedzsment sikerét. (Fawcett et al., 2014)

Az ellátási lánc az alapanyag gyártó vállalat beszállítójától a fogyasztóig tart, mely a beszállítók és az elosztásban résztvevő szereplők láncszerű kapcsolódásával jön létre, amit a folyamatok és áramlások együttesei alakítanak ki és célja, hogy megfeleljen a végső fogyasztói követelményeknek (Vorst, 2004). A piaci igények gyors változása, az igény kielégítés és megfelelési kényszer, és az ellátási lánc szereplőjeként élvezett potenciális előnyök elmaradhatatlan érték, amit a vállalatok nem hagyhatnak figyelmen kívül. Ezekből előnyök csak akkor realizálhatók, ha az ellátási lánc egyes szereplői között kellően erős kohézió és együttműködési formák alakulnak ki. (Morvai - Szegedi, 2015)

Ezért fontos, hogy a vállalatok megfelelő készletezési politikát alkalmazva érjék el a vevői (és tulajdonosi) elégedettséget, ami egyben versenyképességük zálogát jelenti. A tulajdonos elsősorban a profit érdekében müködteti vállalkozását, vagyis elvárása is eköré összpontosul. Azonban ez csak akkor tud megvalósulni, ha a fogyasztók az ellátási láncban létrehozott terméket vagy szolgáltatást olyan mértékben igénylik és vásárolják meg, hogy a tervezett eredmény kielégítse a tulajdonosok elvárásait. (Kozma, 2017). A vevői (fogyasztói) érték akkor képződik, ha a vevő adott tranzakcióból származó haszna meghaladja a kapott termék és szolgáltatáscsomag tulajdonlásának teljes költségét. Tehát elmondhatjuk, hogy a vevői érték az adott termék- és szolgáltatáscsomag észlelt hasznának és a tulajdonlás észlelt költségének a különbsége (Demeter, 2014).

A tulajdonosi értéket általában a vállalat saját tőkéjének piaci értékeként határozzuk meg (Rappaport, 2002), de akár azt is kimondhatjuk, hogy a tulajdonosi érték egyenlő a költségek csökkentésével, ami kimutatható úgy is, mint várható jövőbeni jövedelemtermelő képesség (diszkontált cash flow).

\section{A ,jó” készlet}

A készletezési stratégiája nagymértékben hat a múködés hatékonyságára. A készlet az előre jelzett kereslet, illetve a termelés kiszolgálása érdekében tartott fizikai állomány, mely a vállalat részéről anyagi áldozattal jár. A Lean szerint a készlet tartása egyenlő a pazarlással, mely egyúttal a készletcsökkentés és optimalizálás ösztönzője is. Ez a megközelítés valóban igaz, a készlet hiány ugyanúgy kárt okozhat, mint amikor magas 
készletszinttel dolgozunk. A késztermék készletének hiánya a vállalatra a piaci részesedés elvesztését eredményezheti, ami az árbevétel csökkenésével jár. (Szász - Demeter, 2017)

Amennyiben a készlet nem optimális, a vállalat versenyképességét, kiszolgálási színvonalát csökkentheti, a magas készletszint pedig növeli a logisztikai költségeket, úgymint

- lekötött tőke

- árukezelés, állagmegóvás

- a szükségesnél nagyobb tárolási kapacitás

- a szükségesnél nagyobb mértékű erőforrás felhasználás (hely, munkaerő, stb.)

A készletmenedzsment ismert szállóigéje, hogy „A magas készlet elfedi a hibákat!” Az alacsony készletszint készlethiányos állapothoz vezet. Ezért a megfelelő készletszint meghatározásához tervezni kell:

- $\quad$ keresletet és

- készletezési stratégiát kell kialakítani.

Kereslet tervezés esetén legalább egy éves, lehetőség szerint 3-5 megelőző év időtartamra vonatkozóan tudunk szezonális eltérések figyelembevételével, optimális éves eloszlással, releváns információt kapni. A kereslet előrejelzés bonyolult algoritmusok segítségével is nehezen határozható meg, mert a megelőző év értékesítési adatai a bázist biztosítják, de a fogyasztók szokásainak változását, trendek módosulását nehezen képes kiszámítani. Az egyre inkább terjedő szimulációs rendszerek már képesek olyan futtatásokat is végezni, amelyek akár a jövőre vonatkozó gazdasági prognózist, az egyes termékek életszakaszuknak megfelelő alakulását, vagy a termékek kedvezményes áron értékesítését is képes figyelembe venni.

A jól meghatározott kereslet hozzájárul a megfelelő készletszint tervezéséhez, illetve a folyamatos vevői igény, mint információ átadása, az ostorcsapás-hatás elkerülését teszi lehetővé. Az ostorcsapás hatást kiválthatja a (Szász - Demeter, 2017)

- kereslet-előrejelzés ritka felülvizsgálata,

- rendelések összevonása,

- áringadozások és

- hiány- vagy hiány közeli készletszint.

Az Ostorcsapás-hatás olyan jelenség, mely megfelelő készletszint esetén is kialakulhat az ellátási láncban, amennyiben a megfelelő információáramlás az ellátási lánc szereplői 
között nem kielégítő, vagy ha nagyobb értékesítési volumenre merül fel igény, mint azt előrejelzés alapján terveztünk.

A készletezési stratégia a vállalat döntése, mely az egyes termékekre, cikkelemekre, alapanyagokra, félkész- és késztermékekre vonatkozóan, értékesítési terv alapján választható meg. Az értékesítési terv általában forgalom növekedés figyelembevételével kerül elfogadásra, amely egyrészről a tulajdonosok elvárását foglalja magában, másrészről pedig a piaci versenyből adódó növekedés és az ahhoz tartozó elvárásokat foglalja magában.

A készlettervezést segítő elemzési módszerek:

- ABC elemzés,

- XYZ elemzés,

- Készletforgási mutatók vizsgálata,

- Szezonalitás és trend vizsgálat,

- Beszállítók értékelése.

Az ABC elemzéssel, Pareto-elv alapján határozhatjuk meg, hogy mely termékek, milyen arányban járulnak hozzá az árbevételhez. Az ABC analízis a strukturált probléma egyik fontos eszköze. A készlet tételeit, azok fontossága alapján csoportosítja, illetve a csoportok szerint differenciált gazdálkodási módszereket alkalmaz. Vegyük a tételek számát $100 \%$-nak, melynek első $20 \%$-a az „A”, a következő $40 \%$ a „B”, és a további $40 \%$ a „C” csoportot jelenti. A felosztás tetszőlegesen megválasztható, azonban a gyakorlati példák ezt vagy e körüli arányokat alkalmaznak. A fenti eloszlás Lorenz-görbével ábrázolva arra mutat rá, hogy az „A" termékek a forgalom kb. 80 \%-át biztosítják. A vizsgálatot a következőképpen ajánlott elvégezni:

- teljes- és negyedéves időszakokra,

- globálisan (összvállalati termék szinten) és termékkörökként,

- $\quad$ kis- és nagykereskedelmi értékesítés oldalról,

- árbevétel, árrés és mennyiség (kg) dimenzióban.

Gyakorlati példa a készletek elemzésére

A vizsgált vállalat (Diego Kft.) termékeit 3 különböző módon végeztük el. Először árbevétel, majd árrés, végül mennyiség szempontok szerint. 


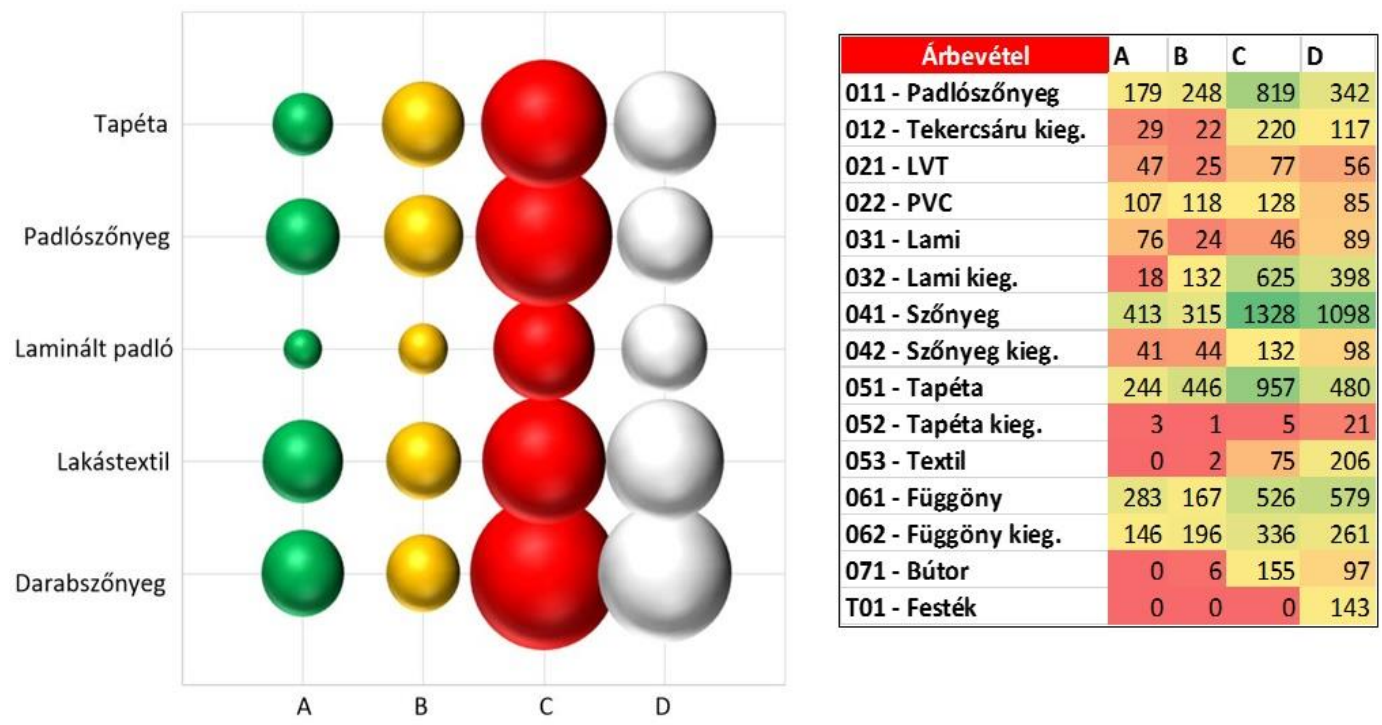

3. ábra: A Diego termékeinek ABC elemzése, árbevétel alapján

Forrás: Diego Kft adatbázisa

A 3. ábra látható, hogy a különböző cikkelemek termékcsoporton belül milyen arányban járulnak hozzá az árréshez (értékesítés haszna), amit a táblázat számadatai alapján szemléltetünk.

A „D” csoportba került termékek olyan cikkeket foglalnak magukban, melyekből további beszerzés nem várható, de a készlet kifuttatásáig hatással van a többi termék forgalmára, illetve kifuttatásukig továbbra is foglalkozni kell velük. Az esetek többségében a vállalatok ABC elemzés készítésekor ezzel a kategóriával nem számolnak, ami miatt komoly eltérések lehetnek a modellezés és s valós állapot között.

A 4. ábra a termékek $\mathrm{ABC}$ elemzését árrés szempont szerint mutatja be:

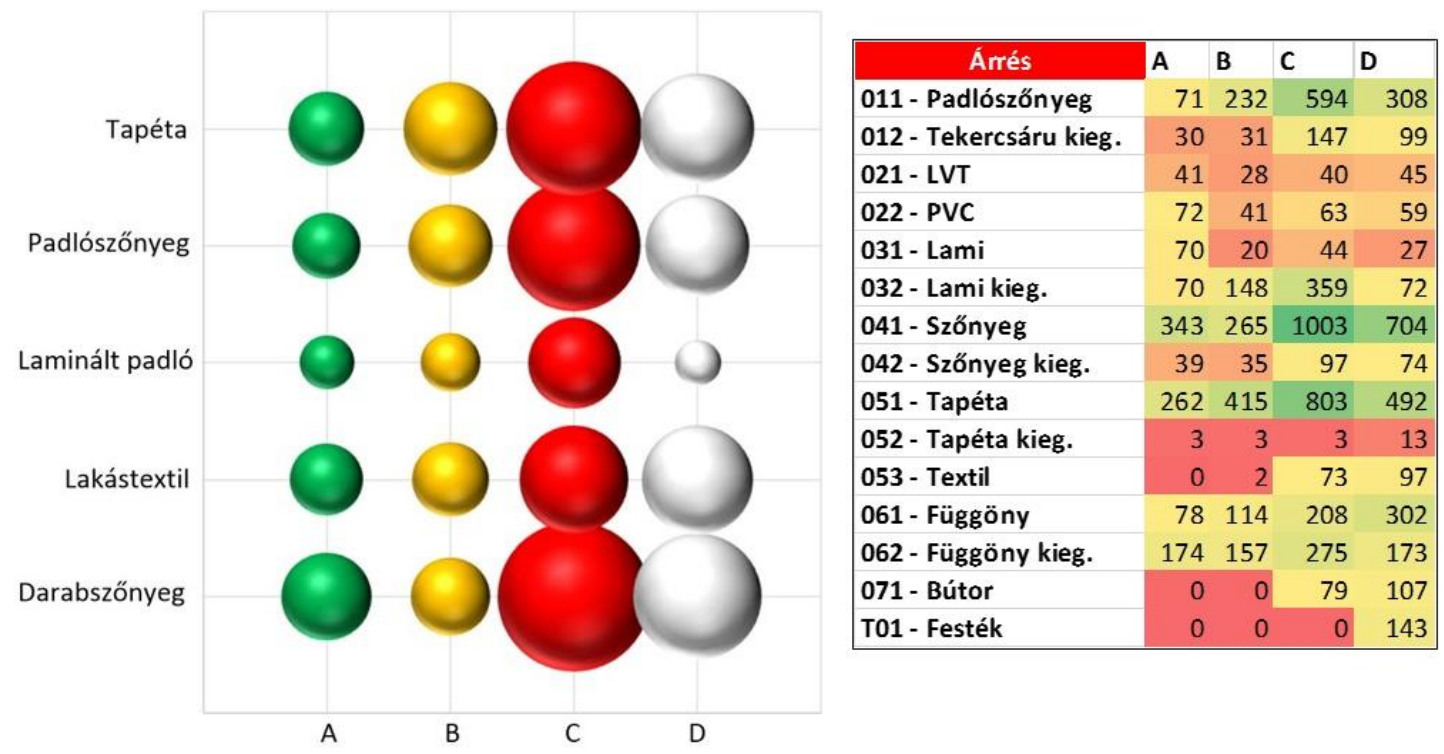

4. ábra: A Diego termékeinek ABC elemzése, árbevétel alapján

Forrás: Diego Kft adatbázisa 
Megfigyelhető, hogy a Pareto-elv itt is igazolásra kerül, hiszen kb. a termékek kb. 20 \%-a biztosítja az árrés 80 \%-át. Fontos az ábrán felismerni, hogy a „B” termékek mennyiségét figyelembe véve, hasonlóan járulnak hozzá az árbevételhez és az árréshez, mint az „A” kategóriás termékek.

$\mathrm{Az}$ 5. ábra a mennyiségi megoszlást szemlélteti - az $\mathrm{ABC}$ elemzés eredményeit naturáliában kifejezve:

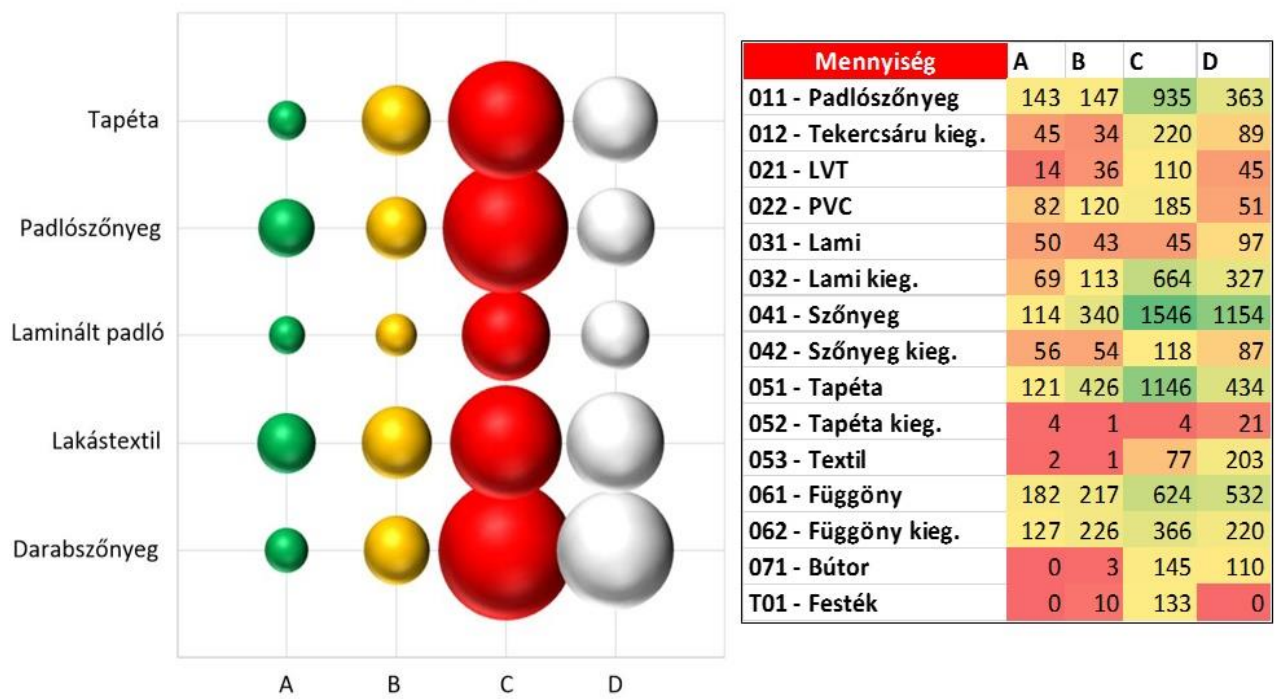

5. ábra: A Diego termékeinek ABC elemzése, árbevétel alapján

Forrás: Diego Kft adatbázisa

A táblázat számadatai, és a grafikon is kiválóan mutatja, hogy az értékesített mennyiség nagyobb része nem az „A" és „B” kategóriás termékek, hanem elsősorban a „C”, majd a „D” kategóriába tartozók. Ez azt jelenti, hogy (figyelembe véve az árrés és árbevétel adatokat is), a kevesebb eladási számú „A” és „B” kategóriás termékek nagyobb hasznot és forgalmat eredményeznek, mint a nagy mennyiségben értékesített „C” és „D” kategóriás termékek. Ne felejtsük el, hogy ezek a termékek nem csak nagyobb értékesítési mennyiségükkel, hanem a ráfordított fizikai munka mennyiségével is kiemelkednek. Az ábrák alapján azt a következtetést vonhatjuk le, hogy készletfigyelés szempontjából az „A", illetve a „B” termékekre kell nagyobb hangsúlyt fektetni, és a megfelelő készletezési mechanizmust választani.

A készletezési mechanizmusok megválasztása termékenként értendők, és időszakosan felül kell vizsgálni. A forgalmi adatok elemzése, a termék keresletváltozása és életciklusából következő változások alapján rendszerint változtatni kell a készletezési mechanizmuson is. A 6. ábra foglalja össze a készletezési mechanizmusok lehetséges változatait, mely a mikor és mennyit kérdésekre adott válaszok alapján 4 stratégia kombináció különböztethető meg. 
Készletezési mechanizmusok az alábbiak lehetnek:

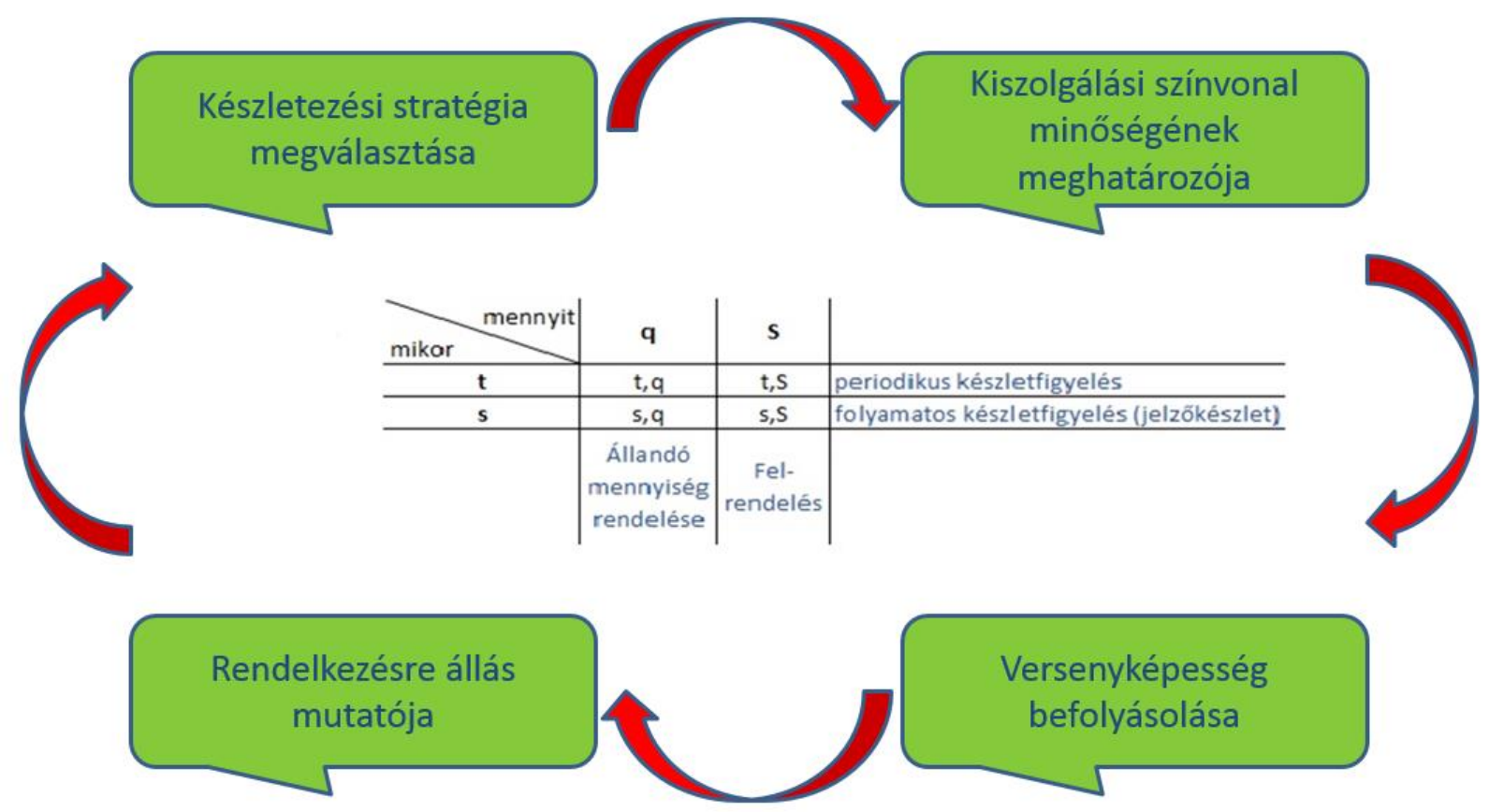

6. ábra: A lehetséges készletezési mechanizmusok táblázata

Forrás: Saját szerkesztés

A táblázatban „q" a mennyiséget, „t” az időt, „s” a készletszintet, míg „S” a maximális készlet szintjét jelöli. A táblázat körül elhelyezett megjegyzések a helyesen megválasztott mechanizmusforma esetén fellépő hatásokat és azok egymásra utalását ábrázolja.

Az XYZ elemzéssel a kereslet ingadozását vizsgáljuk. Az elemzést el kell végezni:

- éves időszakra,

- minden termék vonatkozásában,

- heti és havi aggregáltsággal,

- $\quad$ kis- és nagykereskedelmi értékesítés figyelembevételével,

- mennyiségre, igény megjelenésének időközére,

- a termék által lefedett időszakra.

A készleteket megfelelő kezeléséhez paraméterezéseket szükséges elvégezni:

- negyedéves átlagkészlet,

- negyedéves összesített értékesítés,

- forgási sebesség: azt adja meg az adott időszakra, hogy az átlagos készlet átlagosan mennyi időre (hány napra) elegendő, vagyis hány nap alatt cserélődik le a készlet,

- fordulatszám: azt adja meg az adott időszakra, hogy átlagosan hányszor fordul meg az átlagos készlet.

A beszállítók a készletezés szemszögéből, az ellátási lánc fontos szereplői. Értékelésüket rendszeres időközönként azért kell elvégeznünk, hogy pontosan megtudjuk határozni a 
készletezési stratégiát (mechanizmust), melyet a beszállító által szállított termékekre alkalmaznunk. A beszállító értékelés lehetőséget ad stratégiai kapcsolatok kiépítésére, illetve az elvárások alatt teljesítő beszállítóra felhívni a figyelmet. A megfelelő készletszint tehát nem csak a jól megválasztott mechanizmuson alapszik, hanem a jól teljesítő beszállítón is.

A kiszolgálási színvonal egy relatív mutató, melynek mérése nehezen megvalósítható, relatív és abszolút mutatók segítségével. A készlet nagyban határozza meg, hogy a rendelések teljesítését milyen arányban tudjuk teljesíteni, hogy képesek vagyunk-e a tervezett teljesítés arányát 100 \% vagy annak közelében tartani.

\section{Összefoglalás}

A megfelelő készletszint meghatározza a vállalat rendelkezésre állását, piaci pozícióját, és az ellátási láncban vevőinek megítélését. A magas készlet elfedi a hibákat! Azonban az optimális készletszint likvid tőkét biztosít a vállalat működéséhez, melyen keresztül a tulajdonosok elégedettsége is teljesül. A készlet a vállalat rugalmasságát és rendelkezésre állását is meghatározza, ami a vevő egyik legfontosabb elvárása, vagyis az elégedettség egyik eszköze. Megfelelő készletszint mellett hatékony erőforrás felhasználás valósítható meg, azonban szükséges a készlet minden elemének rendszeres elemzése árbevétel, árrés, és mennyiség szerint.

A megfelelő készletezési mechanizmus megválasztása a hiánymentes készletállapot elérését célozza, illetve azt, hogy a készletek nagysága ne legyen eltúlzott. A készletezési mechanizmus megválasztásán felül komoly szerepe van a megbízható beszállítónak is. A beszállítók értékelése, és azok kiválasztása, szinten tartása fontos feladat, ugyanis a vállalat teljesítményét, megbízhatóságát határozza meg. A megfelelő beszállító elemzés eredménye a megfelelő készletezési stratégia kialakításának lehetősége.

Megfelelő készletszint = versenyképes ellátási lánc!

\section{Irodalomjegyzék}

[1] Chikán A. (2008): Az értékteremtő folyamatok menedzsmentje. Budapest, Akadémia Kiadó

[2] Demeter, K. (2014): Termelés, szolgáltatás, logisztika. Az értékteremtés folyamatai: Budapest, Wolters Kluwer Kiadó

[3] Fawcett, Stanley E. - Ellram, Lisa M. - Ogden, Jeffrey A. (2014): Supply Chain Management From Vision to Implementation. Harlow, Pearson Education Limited

[4] Gelei A. (2013): Logisztikai döntések - fókuszban a disztribúció. Budapest, Akadémia Kiadó 
[5] Kozma, T. (2017): Cooperation in the supply chain network. Forum Scientiae Economia 5 : 3 pp. 45-58., 14 p.

[6] Morley, M. (2017): Supply Chain Analitics for dummies. John Wiley and Sons, Ltd. Chichester, West Sussex

[7] Morvai, R. - Szegedi, Z. (2015): Erőviszonyok az Élelmiszeripar Ellátási Láncában. Vezetéstudomány, XLVI. Évf. 2015. 2. Szám / ISSN 0133-0179

[8] Némon Z. - Sebestyén L. - Vörösmarty Gy. (2005): Logisztika - Folyamatok az ellátási láncban, Kereskedelmi és Idegenforgalmi Továbbképző Kft. Kiadásában, Budapest, 83. o.

[9] Oláh, J. - Karmazin, Gy. - Lakner, Z. - Popp, J. (2017): Az időlapú verseny hatása a logisztikai szolgáltatók tevékenységére és rugalmasságára az ellátási láncban. Controller Info, 5(3), pp. 30-36.

[10] Rappaport, A. (2002): A tulajdonosi érték - Útmutató vállalatvezetőknek és befektetőknek. Budapest, Alinea Kiadó

[11] Szász L. - Demeter K. (2017): Ellátásilánc-menedzsment, Budapest, Akadémia kiadó, 182. 0 .

[12] Van der Vorst, Jack (2004): Supply Chain Management: theory and practices. https://app.box.com/s/lzd9y0svqdl6h8y13waep0t8p19cr819/file/430949225646, Letöltés ideje: 2019. július 23. 